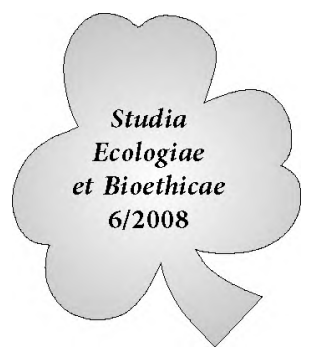

\title{
Dylematy wychowania XXI wieku a rozwój zrównoważony
}

\begin{abstract}
Wstęp
Wiek XXI skłania nas do refleksji nad rolą i kształtem wychowania we współczesnym świecie.

Wśród współczesnych dylematów wychowania problem odpowiedzialności za siebie, innych i środowisko, w którym się żyje, jest szczególnie istotny. Wychowanie, jeśli ma spełnić pokładane w nim nadzieje, nie może być zbyt oderwane od życia (Pikus, 2001, s. 178). Spektakularne osiągnięcia nauki, szybkie tempo życia w dobie komputeryzacji stały się wyzwaniem dla nauk pedagogicznych, dlatego wychowanie musi uwzględniać zmianę warunków życia spowodowaną rozwojem cywilizacyjnym oraz wzrostem prestizu nauki i techniki. Szybki rozwój niestety niesie ze sobą konieczność dokonywania ciągłego wyboru oraz umiejętność odróżniania wartości pozytywnych od negatywnych.

Realizacja zadań przybliżających działania szkoły do wymogów codziennego życia, wymusza nowe oddziaływania edukacyjne. Dobroczynny wpływ przyrostu wiedzy naukowej, jej zastosowanie oraz postęp naukowo-techniczny wywołują często w społeczeństwie niepokój i obawy, które rozpraszane są poprzez wspieranie kształcenia od najmłodszych lat z jednoczesnym określeniem zasad etycznych, określając jednocześnie zasady etyczne (Biała Księga, 1997, s. 7). Człowiek nieustannie ingeruje w środowisko, a rozwój cywilizacji uważa za najważniejsze dobro oraz panaceum na wszelkie problemy współczesnego świata. W obliczu konieczności zmieniających się warunków życia istnieje silna potrzeba określenia właściwych metod i kierunków w wychowaniu pożądanych dla przyszłego pokolenia.
\end{abstract}

\section{Rozwinięcie}

Dylematem współczesnego wychowania jest konieczność ukształtowania takiego poczucia odpowiedzialności za świat, aby działania, podejmowane zarówno w życiu prywatnym jak i zawodowym, były ściśle kontrolowane i nie wpływały negatywnie na środowisko oraz na człowieka. Efektywne poczucie odpowie- 
dzialności powinno wskazywać proekologiczne zachowania pozwalające chronić środowisko i pozostawić je w zadawalającym stanie następnym pokoleniom. Roli wychowania w tym zakresie nie da się przecenić. Jest ono, zdaniem Okonia (1984, s. 346) świadomie organizowaną działalnością społeczną, której celem jest wywoływanie zamierzonych zmian w osobowości człowieka. Zmiany te polegają na kształtowaniu stosunku człowieka do świata i ludzi, jego przekonań i postaw, układu wartości i celu życia. Ukształtowanie poczucia odpowiedzialności u jednostki jest istotnym wskaźnikiem osobistego rozwoju. Pozwala na podejmowanie słusznych decyzji, na prawidłowe wybory i działanie dla dobra swojego, innych i środowiska. Obecnie ludzi nie cechuje poczucie odpowiedzialności za świat. Zdaniem Fikusa (1997, s. 202) głównymi przeszkodami takiego stanu rzeczy jest:

- głód w niektórych rejonach świata i konsumpcyjny styl bycia w innych;

- brak dostatecznej wiedzy o zagrożeniach i ich przyczynach;

- nieuświadomienie związków istniejących między własnymi zachowaniami i sytuacją w środowisku społecznym i przyrodniczym.

Wychowanie współczesnego pokolenia jest bardzo trudne. Nie może się ono przystosować do obecnych warunków, zagrożeń i nieprawidłowości. Kolejne pokolenie powinno nie tylko posiąść znacznie większą wiedzę na temat środowiska, ale przede wszystkim proekologiczne postawy i nawyki, które pozwolą naprawiać otaczającą ich rzeczywistość. \o bardzo trudne zadanie edukacyjne wymusza szereg zmian i nowe podejście do wychowania. Konieczność tych działań wynika z potrzeby kształtowania u ludzi nowego paradygmatu kulturowego, ukierunkowanego na zrównoważony, czyli optymalny w danych warunkach dla człowieka i biosfery rozwój (Pikus, 2001, s. 178). Ponieważ za realizację założeń zrównoważonego rozwoju odpowiedzialne są rządy państw, władze lokalne, ale przede wszystkim każdy z nas, edukacja musi odpowiednio przygotować jednostki do podejmowania odpowiedzialnych decyzji. Niszczenie środowiska, chęć jego podporządkowania często jest wielkim problemem lokalnym, zarówno w miastach, jak i wsiach. Związany jest on z obecnością człowieka i chęcią luksusowego życia. Wraz z rozwojem cywilizacji wydawać by się mogło, że wszystkie sprawy potrafimy kontrolować. Niestety, nie umiemy wykorzystać osiągnięć cywilizacyjnych dla obrony środowiska. Czym wyższy poziom rozwoju tym większa chęć panowania nad przyrodą i wykorzystywania jej zasobów. Rozwój cywilizacji powinien pomagać w likwidacji kłopotów egzystencjalnych poprzez przygotowanie dzieci i młodzieży do krytycznej oceny stanu realiów życiowych i do odpowiedzialnego sterowania własnym rozwojem. \o trudne edukacyjne przedsięwzięcie powinno być prowadzone systematycznie, aby trwale ukształtować postawy młodych ludzi.

Wychowanie powinno zaspakajać potrzeby społeczne teraz i w przyszłości. Niekorzystne zmiany w środowisku będą możliwe do zredukowania, gdy edukacja ekologiczna będzie skuteczniejsza. Działania podejmowane przez szkoły powinny wpływać na zmianę zachowań i nawyków wśród dzieci i dorosłych 
mieszkańców. Koniecznym jej elementem jest odpowiednie przygotowanie uczniów do podejmowania racjonalnych działań, służących ochronie przyrody, poprawie stanu środowiska, dostrzegania zagrożeń cywilizacyjnych oraz rozwiązywania problemów stwarzanych w środowisku przez człowieka (Cichy, 2002, s. 19). Coraz częściej widzimy zależności między własnym życiem a stanem środowiska, w którym żyjemy. Nowy paradygmat rozwoju, wynikający z realizacji zasady zrównoważonego rozwoju, pozwala ujmować łącznie rozwój gospodarczy, społeczny i ochronę środowiska w celu zapewnienia możliwości zaspakajania potrzeb i aspiracji współczesnego i przyszłych pokoleń. Wymusza to konieczność takiej edukacji młodego pokolenia, która stworzy warunki umożliwiające nauczenie się innego modelu konsumpcji, wydajniejszego i nakierowanego nie tylko na poprawę naszej własnej jakości życia, lecz także tych, którzy wytwarzają dobra konsumpcyjne. Wobec degradacji środowiska naturalnego, lansowanego współcześnie na świecie rozwoju gospodarczego z jego wzorami produkcji i konsumpcji powodującymi narastanie ryzyka ekologicznego, społeczność międzynarodową, ludzie nauki, uznają, iż jedynie trwały, zrównoważony rozwój może stanowić cel wspólnoty światowej w drodze do utrzymania życia na Ziemi (Kurdybacha, 2005, s. 174).

Przygotowaniem dzieci i młodzieży do pełnienia różnych ról społecznych zajmuje się szkoła. Edukacja przeprowadzona przez nią powinna przedstawiać szerokie spektrum problematyki środowiskowej. Sama wiedza o problemach środowiskowych jest niewystarczająca, trzeba wyzwolić u uczniów chęć działania na rzecz środowiska i spowodować, że będą sami podejmować takie działania w ich życiu codziennym.

Droga od teorii do praktyki nie jest prosta, dlatego potrzebne są dobre pomysły na przekazanie uczniom w ciekawy sposób wiedzy, przybliżając znaczenie harmonii między aspektem przyrodniczym, społecznym, ekonomicznym, kulturowym i gospodarczym w każdym ludzkim działaniu. Do postrzegania problemów egzystencjalnych przez pryzmat konieczności zachowania równowagi w środowisku powinna przygotować szkoła. 囚o wyzwanie polega na pobudzeniu młodych umysłów do zbudowaniu takiego modelu gospodarczego, który zapewni postęp ludzkości, nie niszcząc wspierających go systemów i umożliwi wszystkim podniesienie jakości życia. \aki model gospodarczy będzie mógł funkcjonować tylko w zgodzie z ideą zrównoważonego rozwoju.

Edukacja środowiskowa to nie tylko teoria lecz przede wszystkim kształtowanie osobowości, postaw i nawyków. Szkoła poprzez swoje działania - stara się zmieniać nastawienie dzieci i młodzieży do spraw środowiska naturalnego.

Cele edukacji ekologicznej określone zostały w Narodowej Strategii Edukacji Ekologicznej. Edukacja na rzecz zrównoważonego rozwoju realizuje następujące cele: 
1. Kształtowanie pełnej świadomości i budzenie zainteresowania społeczeństwa wzajemnie powiązanymi kwestiami ekonomicznymi, społecznymi, politycznymi i ekologicznymi.

2. Umożliwienie każdemu człowiekowi zdobywania wiedzy i umiejętności niezbędnych dla poprawy stanu środowiska.

3. Ðworzenie nowych wzorców zachowań, kształtowanie postaw, wartości i przekonań jednostek, grup i społeczeństw, uwzględniających troskę o jakość środowiska.

Żeby wykazać zależności między poszczególnymi dziedzinami rozwoju, trzeba przeprowadzić szereg zajęć w terenie, dokonać wielu obserwacji i szczegółowych analiz. Wymaga to olbrzymiej wiedzy nauczyciela oraz umiejętności pracy w terenie, we współpracy ze środowiskiem lokalnym.

Wiek XXI to wielkie wymagania wobec edukacji. Społeczeństwo oczekuje takiego przygotowania ludzi przez szkołę, aby nie tylko potrafili korzystać ze zdobyczy współczesnej cywilizacji, ale także byli kreatywnie nastawieni do życia, aby ich udział w kreowaniu rzeczywistości był aktywny oraz pełny twórczego uczestnictwa w procesie jej dalszego istnienia i rozwoju.

Na przełomie roku 2006 i 2007 poddano analizie 43 programy wychowawcze szkół podstawowych, gimnazjów i szkół ponadgimnazjalnych. 27 z nich pochodziło ze szkolnych stron internetowych, a 16 bezpośrednio ze szkół warszawskich. Badania te umożliwiły jednocześnie rozmowę z nauczycielami i wychowawcami.

W znacznej części tych dokumentów znajdują się zapisy dotyczące oczekiwanej sylwetki absolwenta (ryc. 1). Blisko $70 \%$ programów wychowawczych zawiera tylko wymienione cechy absolwenta, $14 \%$ zawiera opis cech i umiejętności, jakie powinien nabyć uczeń podczas nauki szkolnej oraz ich znaczenie w życiu dorosłym. Niestety, aż $16 \%$ programów wychowawczych nie informuje o skutkach podejmowanych działań wychowawczych.

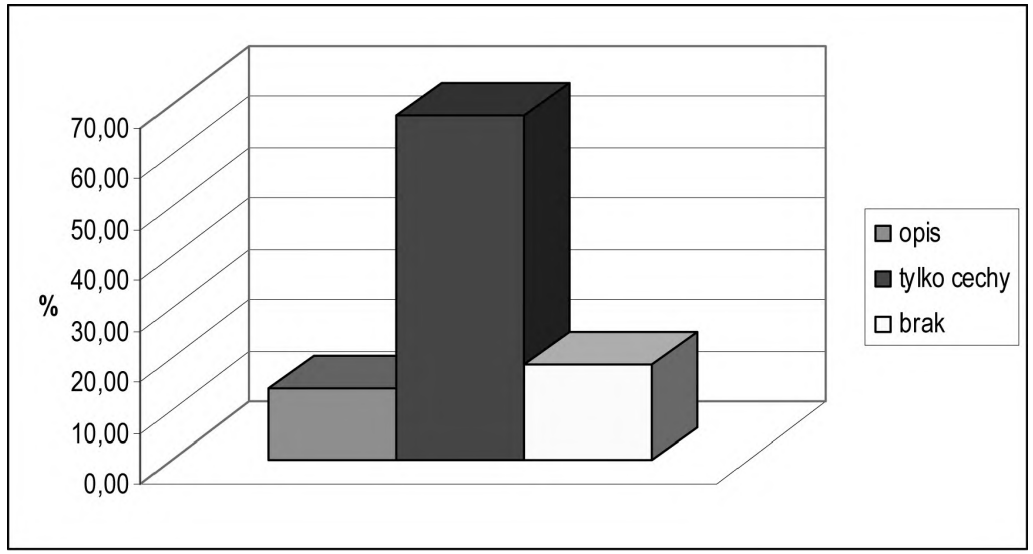

Ryc. 1. Zapisy dotyczace sylwetki absolwenta zamieszczone w programach wychowawczych 
$\mathrm{Z}$ analizy programów wychowawczych wynika, że naczelnym celem wychowania szkolnego jest pełny rozwój młodego człowieka, a w szczególności:

- przygotowanie każdego ucznia do wykonywania zadań w życiu zawodowym i publicznym;

- wykształcenie szacunku dla rzetelnej pracy i zdobywania wiedzy;

- rozwijanie ciekawości świata i indywidualnych zainteresowań;

- rozwijanie samodzielności, przedsiębiorczości i poczucia odpowiedzialności;

- przygotowanie do życia w rodzinie i innych wspólnotach, takich jak: klasa szkolna, wspólnota lokalna, państwo;

- dbanie o rozwój sfery życia duchowego i emocjonalnego;

- wyrabianie umiejętności dokonywania właściwych wyborów moralnych i hierarchizacji wartości;

- kształtowanie wysokiej kultury osobistej;

- przekazanie dziedzictwa kulturowego i kształtowanie postaw patriotycznych;

- uświadomienie praw i obowiązków ucznia;

- przestrzeganie wspólnie ustalonych norm zachowania;

- uczenie szacunku dla wspólnego dobra i własności prywatnej;

- dbałość o zdrowie i rozwój sprawności ruchowej;

- kształtowanie troski o środowisko naturalne.

Analizując treści zamieszczane w różnych programach szkolnych należy wyciągnąć wniosek, że głównym celem wychowawczym nie jest tylko adaptacja dzieci do aktualnych warunków życia, ale przygotowanie ich do kierowania i wpływania na życie swoje i innych oraz do funkcjonowania w środowisku. Đylko część dokumentów zawiera wskazanie konkretnych do podjęcia działań, aby wymienione w planie zamierzenia zostały zrealizowane (ryc. 2). Listę działań podejmowanych przez nauczycieli w celu realizacji podstawowych zadań szkoły zawiera blisko $49 \%$ badanych dokumentów. Duża grupa szkół skupiła się jedynie na podaniu celów wychowania i zadań szkoły z tym związanych, nie wymienia jednak działań podejmowanych przez pedagogów (30\%).

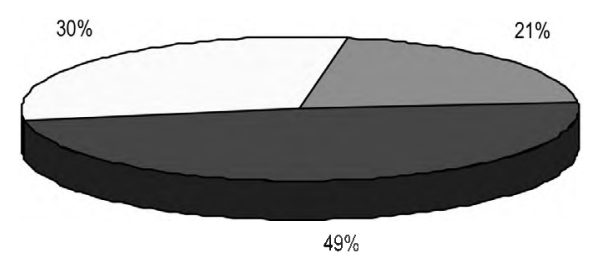

Ryc. 2. Dzialania podejmowane przez nauczycieli wymieniane w programach wychowawczych 
W niewielu programach wychowawczych znajdują się szczególowe cele wychowawcze, a tylko kilka $z$ nich zawiera podział celów wychowawczych na poszczególne dziedziny umiejętności szczególnie je kształcące. Wymogi współczesnej cywilizacji stawiają przed szkołami konieczność rozszerzania tradycyjnych celów wychowawczych o nowe, wynikające z zachodzących dynamicznych zmian cywilizacyjnych. Do tych celów zaliczyć można konieczność wpojenia wychowankom norm i sposobów postępowania w domenie ekologii i ochrony środowiska, świata mediów, druku i informacji oraz edukacji prozdrowotnej. Wskazanie działań szczegółowych, wynikających z realizacji nowych grup tematycznych, zawiera 17\% analizowanych dokumentów (tab. 1).

Tabela 1. Przykladowy zapis zamieszczony w programie wychowawczym.

WYCHOWANIE PROEKOLOGICZNE:

\begin{tabular}{|c|c|c|c|}
\hline $\begin{array}{l}\text { Zadanie szcze- } \\
\text { gółowe }\end{array}$ & Uczeń potrafi: & Sposób realizacji & Odpowiedzialni \\
\hline $\begin{array}{l}\text { Kształtowanie } \\
\text { wrażliwości na } \\
\text { estetykę oto- } \\
\text { czenia }\end{array}$ & $\begin{array}{l}\text { — być wrażliwy na } \\
\text { piękno przyrody; } \\
\text { — wykazać się } \\
\text { podstawową wiedzą } \\
\text { z zakresu ekologii; } \\
\text { — wskazać zagro- } \\
\text { żenia środowiska } \\
\text { naturalnego; }\end{array}$ & $\begin{array}{l}\text { 1) systematyczne dbanie o rośliny } \\
\text { doniczkowe kwiaty w klasach; } \\
\text { 2) sadzenie drzew przez uczniów } \\
\text { klasy; } \\
\text { 3) przygotowanie sadzonek } \\
\text { kwiatów z nasion; } \\
\text { 4) udział w akcji „Sprzątanie } \\
\text { świata”; } \\
\text { 5) wycieczka do schroniska dla } \\
\text { zwierząt połączona z instruktażem } \\
\text { "Jak prawidłowo opiekować się } \\
\text { zwierzętami”; } \\
\text { 6) zorganizowanie konkursu } \\
\text { plastycznego o tematyce ekologii; } \\
\text { 7) przeprowadzenie pogadanki } \\
\text { na temat: „Dlaczego należy dbać } \\
\text { o czyste powietrze?”; } \\
\text { 8) zorganizowanie konkursów } \\
\text { plastycznych: „Najpiękniejszy } \\
\text { pejzaż zimowy”, „Przywitanie } \\
\text { wiosny” } \\
\text { 9) zorganizowanie wycieczki do } \\
\text { oczyszczalni ścieków }\end{array}$ & $\begin{array}{l}\text { wychowawcy klas; } \\
\text { opiekun LOP, } \\
\text { wychowawca; } \\
\text { opiekun LOP; } \\
\text { wychowawcy klas; } \\
\text { opiekun LOP; }\end{array}$ \\
\hline
\end{tabular}

W nielicznych programach przedstawiona jest bogata oferta zajęć pozalekcyjnych. Szczególnie te dziedziny edukacji i wychowania, które wychodzą naprzeciw zapotrzebowaniom rozwojowym dzieci i młodzieży, a jednocześnie przybliżają do rozwiązywania aktualnych problemów środowiska lokalnego, cieszą się du- 
żym zainteresowaniem. Część młodzieży widzi konieczność udziału w takich formach edukacyjnych, dzięki którym poznaje potrzeby ogólnospołeczne, może nabyć umiejętność kierowania swoją dalszą drogą życiową, mającą wpływ na karierę zawodową.

Niestety, znaczna część dzieci i młodzieży żyje w środowisku, w którym dominują tendencje wzrostu postaw konsumpcyjnych i egoistycznych. W konsekwencji przyjęcie takich nieprawidłowych zachowań prowadzi do rozwijania się postaw agresywnych, występowania zjawisk patologii społecznej i degradacji moralnej rodziny i społeczeństwa. Współczesne procesy edukacyjne powinny przygotowywać młode pokolenie do realiów życia poprzez własną aktywność. Ponieważ znacznie trudniej jest naprawiać błędy niż budować nową rzeczywistość, dzieci i młodzież powinny być przygotowane do pokonywania trudności. Należy pamiętać, że tylko kreatywni ludzie i kreatywne rozwiązania są szansą dla rozwoju cywilizacji w zgodzie z naturą. Dzieci, które wkrótce dorosną i zasiądą na wysokich stanowiskach, będą musiały naprawiać obecną rzeczywistość. W procesie wychowania nauczyciele muszą, jak nigdy dotąd, położyć nacisk na umiejętność krytycznego oceniania rzeczywistości i podejmowania słusznych decyzji uwzględniających rozwój własny, społeczny oraz stan środowiska naturalnego.

Wychowawcy - podejmując obecnie realizację zadań wychowawczych - muszą brać pod uwagę zmiany zachodzące w świecie, zanikanie więzi rodzinnych, obniżający się stale status ekonomiczny rodziny, co wpływa niekorzystnie na kształtowanie postaw młodego pokolenia. Populistyczne hasła, przemoc i agresja w mediach, załamanie wielu tradycyjnych form i wzorów postępowania, utrudniają młodym ludziom podejmowanie prawidłowych decyzji i tylko edukacja może przyczynić się do weryfikacji podejmowanych wyborów oraz trwałych stylów i sposobów życia.

Powszechne zainteresowanie budzi ostatnio stan przyrody i środowiska. Zawsze poznawanie najbliższego otoczenia stanowiło pierwszy krok w kierunku poznania zależności człowieka od niego i od przyrody. Obecnie powodem pogarszającej się jakości środowiska jest często zanieczyszczenie najbliższego otoczenia przez każdego $\mathrm{z}$ nas.

Dotychczasowy system edukacji nie spełnia pokładanych w nim nadziei, związanych z kształceniem świadomości ekologicznej i edukacją dla rozwoju zrównoważonego. Wydaje się, że jedynym sposobem by temu zaradzić, są zmiany systemowe w oświacie. Głównym zadaniem edukacji ekologicznej jest doprowadzenie ludzi - tak w aspekcie jednostkowym, jak i zbiorowym - do rozumienia istniejących w środowisku zależności i wzajemnych oddziaływań w wymiarach: fizycznym, biologicznym, społecznym, ekonomicznym czy kulturowym (Kurdybacha, 2005, s. 177). Niestety, obserwując podejmowane przez szkoły 
działania zauważyć można brak skuteczności i niemoc wpływania na postawy i nawyki całego społeczeństwa. Kształcenie dla rozwoju zrównoważonego weszło do szkół, ale nie jest realizowane w nich według określonych standardów. Część szkół w swoich programach wychowawczych określa cele edukacji ekologicznej zauważając, że ich realizacja wspiera zasadniczo ogóle cele wychowawcze i łączy proces dydaktyczny i wychowawczy, wpływając na postawy, zachowanie i wybór stylu życia. Najczęściej wymieniane w programach są:

- Zapoznanie uczniów z zasadami filozofii ekologicznej celem wykształcenia świadomości i postaw ekologicznych.

- Ukazanie zależności między działalnością człowieka a jego środowiskiem naturalnym i wynikających $\mathrm{z}$ tego konsekwencji na różnych płaszczyznach: przyrodniczej, społecznej, technicznej.

- Uświadomienie roli ekologii w przewidywaniu efektów nadmiernej ingerencji człowieka w świat przyrody - zatrucie środowiska, zmiany klimatu, kryzys energetyczny, itd.

- Przekazywanie podstawowej wiedzy o ruchach proekologicznych (np. Greenpeace i Partie Zielonych ), badaniach ekologicznych i najnowszych osiągnięciach w zakresie gospodarowania ekosystemami.

- Uwrażliwienie młodzieży na problemy środowiska naturalnego, harmonijne współżycie z przyrodą, ochrona i umiar w korzystaniu z dóbr przyrody ( tzw. partnerstwo ekologiczne ).

- Motywowanie do codziennych, różnorodnych zadań chroniących środowisko.

- Wykształcenie aktywności i odpowiedzialności za losy Ziemi.

- Prowadzenie czynnej edukacji ekologicznej w bezpośrednim kontakcie z przyrodą (plenery, wakacje w terenie, wycieczki, „zielone” lekcje ).

- Organizowanie sesji popularno-naukowych.

\ak bogaty zestaw podejmowanych działań przez szkoły zapewniłby kształcenie i wychowanie dla ekorozwoju, ale poziom realizacji tych zagadnień zależy od zaangażowania nauczyciela i wychowawców klas, podejścia dyrektora szkoły, chętnych do współpracy rodziców oraz władz samorządowych. Brak obowiązku realizowania zagadnień z zakresu edukacji ekologicznej przez jednego nauczyciela powoduje rozłożenie odpowiedzialności za braki w tej wiedzy na wszystkich, a w konsekwencji nie prowadzony jest nadzór realizacji zagadnień z tego zakresu. Jest to jeden z czynników wpływających na opóźnienia we wdrażaniu ekorozwoju. Ważnym uwarunkowaniem, hamującym ekorozwój, jest mała świadomość środowiskowa. Pozornie wzrasta ona, jednak trwa do momentu, kiedy trzeba zrezygnować $\mathrm{z}$ drobnego elementu składającego się na komfort własnego życia codziennego (Cichy, 2000, s. 14).

Nauczyciele sami stwierdzają, że nie są przygotowani do efektywnego kształcenia środowiskowego i prowadzenia zajęć w terenie. Niektóre kierunki przed- 
miotowych studiów nauczycielskich w ogóle nie realizowały przedmiotu edukacja ekologiczna, a kierunki typowo pedagogiczne także nie przygotowują do prowadzenia takich zajęć z uczniami. A przecież jest to tematyka, która powinna być realizowana nie tylko w ramach przedmiotów przyrodniczych, ale także przez wychowawców i omawiana na godzinach przeznaczonych do ich dyspozycji. Zdaniem nauczycieli, w szkołach nie jest egzekwowana efektywna realizacja tematyki z tego zakresu, chociaż często elementy jej realizacji efektownie są eksponowane poprzez wywieszenie prac uczniów, plakatów oraz zdjęć z konkursów i akcji. \ematyka środowiskowa, edukacja ekologiczna, współpraca ze środowiskiem lokalnym nie znalazła się także w priorytetach większości kuratorów oświaty.

Koncepcja ekorozwoju opiera się na założeniach, że gospodarkę kraju należy prowadzić zgodnie z naturalnymi uwarunkowaniami przyrodniczymi (Nowak, 2000, s. 137). Bez działań bieżących, doraźnie wpływających na dorosłą część społeczeństwa i sytuację w gospodarce, nie uda się nic zmienić, ale są to działania kosztowne, wymagające powtarzania i nie wpływające bezpośrednio na zmianę postaw w społeczeństwie. Natomiast edukacja w tym zakresie, o ile będzie obowiązkowa i prowadzona na wszystkich etapach edukacyjnych i w wyższych uczelniach, ma tę przewagę, ze prowadzona systematycznie wprowadza zmiany postaw w całej społeczności. Jej efektem są skuteczne działania i decyzje prośrodowiskowe, podejmowane w życiu prywatnym i zawodowym.

W 16 warszawskich placówkach oświatowych nauczyciele mieli możliwość wskazania barier hamujących wdrażania ekorozwoju (ryc. 3). Podkreślają zgodnie, że edukacja środowiskowa bez wsparcia $z$ zewnątrz w postaci lepszego przygotowania nauczycieli przez wyższe uczelnie, obowiązku realizacji tej tematyki w szkołach oraz podniesienia znaczenia zagadnień ekorozwoju w mediach i szeroko zakrojonej akcji dokształcania dorosłych w tym zakresie, nie ma mocy sprawczej w zakresie zmiany mentalności, postaw i zachowań całego społeczeństwa polskiego.

Należy także mieć na uwadze nasilające się konflikty i zmiany społeczne oraz często wykluczające się bodźce wychowawcze, kształtujące postawy młodego pokolenia. Dostęp do informacji nie pozwala na stosowanie strategii unikania zagrożenia, które dawniej sprawdzała się. 


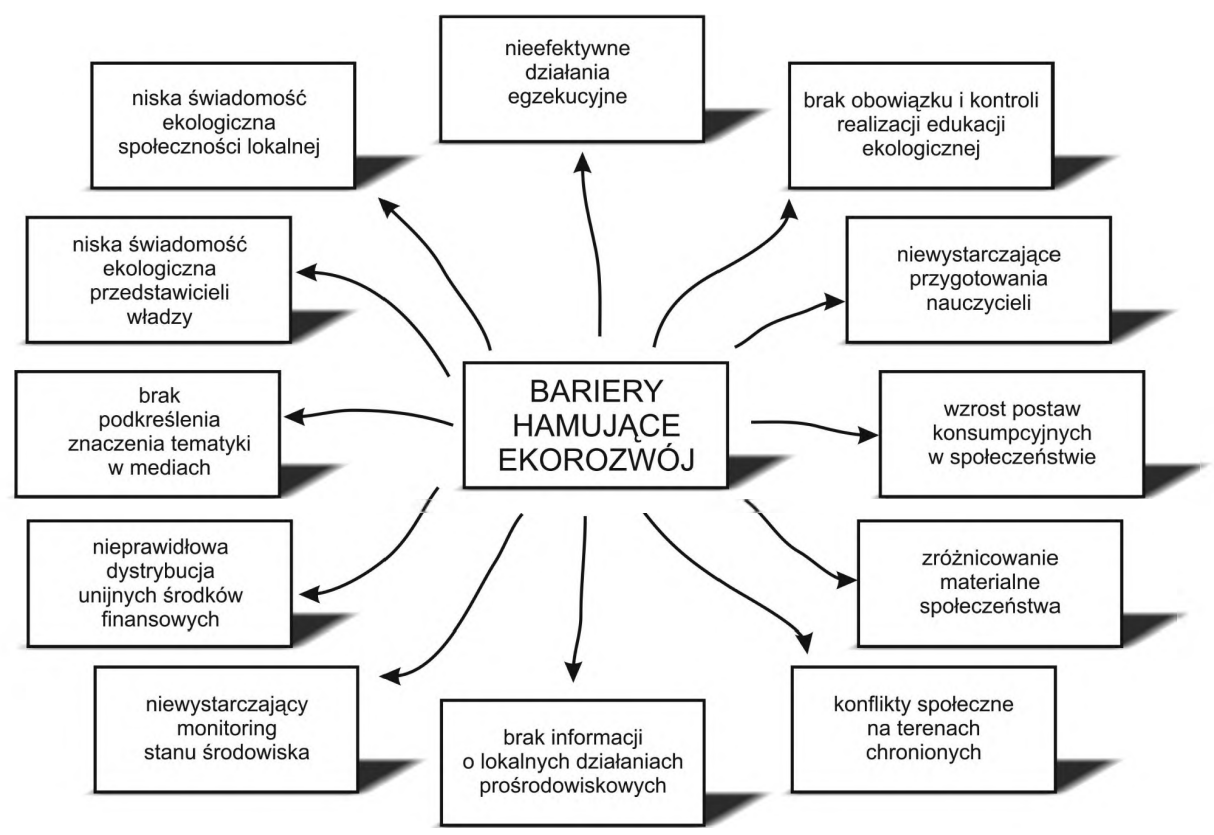

Ryc. 3. Bariery hamujące wdrażanie rozwoju zrównoważonego

\section{Zakończenie}

Obecnie ważną kwestią związaną z wychowaniem dzieci i młodzieży jest odpowiednie ich przygotowanie do radzenia sobie z problemami, wyposażenie ich w umiejętność samodzielnego podejmowania decyzji i racjonalnych wyborów. Ważne jest także nauczenie pracy i wyboru trafnych rozwiązań w stresie oraz umiejętność wykorzystania czasu wolnego w celu odreagowania sytuacji trudnych dla zachowania higieny psychicznej.

Rozwiązanie przedstawionych dylematów zależy od podjęcia działań i współpracy rodziców, wychowawców, samorządu i organizacji pozarządowych mających wpływ na wychowanie dzieci i młodzieży. Przyszły kształt społeczeństwa i stan środowiska zależy od sukcesów związanych z działaniami wpływającymi na wychowanie kolejnego pokolenia przez państwo, uczelnię, szkołę oraz społeczność lokalną, a przede wszystkim rodzinę.

\section{LITERATURA}

Biała Księga Kształcenia i Doskonalenia. Nauczanie i uczenie się. Na drodze do uczacego się społeczeństwa. Komisja Europejska, WSP \WP, Warszawa 1997.

Cichy D., Ewaluacja zmian w edukacji środowiskowej wprowadzonych reformą szkolną, [w:] D. Cichy (red.) Podstawy kształcenie dla zrównoważonego rozwoju, PAN, Warszawa 2000. 
Cichy D., Idee przewodnie kształcenia dla zrównoważonego rozwoju, [w:] D. Cichy (red.) Edukacja środowiskowa założenia i rzeczywistość po reformie szkolnej, PAN, Warszawa 2002.

FIKus S., Różne pojmowanie poczucia moralnej odpowiedzialności za świat. Swiatopogląd i ekologia. WSP, Olsztyn 1997.

Kurdybacha B., Troska o środowisko naturalne w wymiarze globalnym fundamentem edukacyjnej wspólnoty. [w:] Edukacyjna wspólnota na rzecz społeczeństwa dla wszystkich, A. Sajdak (red.), Wydawnictwo UJ, Kraków 2005.

Nowak L., Realizacja idei ekorozwoju w edukacyjnej ścieżce ekologicznej, [w:] D. Cichy (red.) Podstawy kształcenie dla zrównoważonego rozwoju, PAN, Warszawa 2000.

OKоń W., Slownik pedagogiczny. PWN, Warszawa 1984.

PIKus S., Główne przeszkody we wprowadzeniu adekwatnych do potrzeb ludzkości zmian w wychowaniu. [w:] Edukacja ekologiczna wobec wyzwań XXI wieku, J. Dębowski (red.). Wydawnictwo Uniwersytetu Warmińsko-Mazurskiego, Olsztyn 2001.

\title{
Dilemmas of upbringing in the 21 st century versus a balanced development
}

\author{
SUMMARY
}

Among the contemporary dilemmas connected with the upbringing, the issue of responsibility for oneself, for others and for the environment in which we live is particularly important. Therefore, upbringing cannot be separated from life. It can be interpreted as the entirety of human actions aimed at shaping a human being for responsible fulfillment of roles in family and society.

The contemporary generation has a vital task to perform. It should try to remedy the surrounding reality. The change of habits and attitudes of the next generation depends on the educators' fresh outlook on the upbringing. The previous educational system did not meet the hopes pinned on it, and related to developing an ecological awareness. Only education enables bringing the relationships existing in the environment closer. Schools initiate many actions in the field of environmental education. Sadly, the commitment of schools varies greatly and is determined by the activity level of the individual teachers, who are not responsible for the implementation of the environmental topics. The lack of supervision over the introduction of questions from this field and the lack of a person responsible, delay education and upbringing for the eco-development.

It is the hands of the young generation that taking up actions rests in; actions which are not harmful and can even save the closest environment. The role of upbringing in this scope cannot be overestimated. 